\title{
KNOWLEDGE CREATION AND KNOWLEDGE TRANSFER: AN PERSPECTIVE UNDER THE KIBS VISION FOR EVALUATING THE INNOVATIVE CAPACITY
}

\section{CRIAÇÃO DE CONHECIMENTO E TRANSFERÊNCIA DE CONHECIMENTO: UMA PERSPECTIVA SOB A VISÃO DE KIBS PARA AVALIAR A CAPACIDADE INOVATIVA}

\author{
Ronnie J-Figueiredoa \\ Júlio Vieira Neto ${ }^{b}$ \\ João J.M. Ferreirac \\ Osvaldo Luiz Gonçalves Quelhas ${ }^{d}$ \\ Gilson Brito Alves Limae
}

\begin{abstract}
Introduction: The knowledge creation and knowledge transfer constitute the field of interdisciplinary nature whose scientific configuration has been consolidating in the international scope from its relation with the Knowledge Intensive Business Services KIBS. Objective: Explain how the elements of a conceptual model based on KIBS (Knowledge Intensive Business Services) can be applied in an integrated way to assess the innovative capacity of firms in the service sector. Metodology: The building of the model is based on a bibliometric analysis of the central theme KIBS, in the databases Scopus and ISI Web of Knowledge (Web of Science). Results: In this study, it can be seen that during the seventeen years of research, the authors did not investigate the relationship between KIBS and the evaluation of the innovative capacity of firms in the service sector. Conclusion: The greater concentration of the analyzed papers investigates the attributes and roles of KIBS for innovation. It's an opportunity to assess the innovative capacity of KIBS in the service sector.
\end{abstract}

a Doutor em Sistemas de Gestão Sustentáveis - Latec - Universidade Federal Fluminense (UFF). E-mail: rifa77@gmail.com

b Doutor em Engenharia Civil Universidade Federal Fluminense (UFF). Professor do Departamento de Contabilidade da Universidade Federal Fluminense (UFF). E-mail: julio@latec.uff.br

c Doutor em Gestão pela Universidade Beira Interior (UBI). Professor e Pesquisador em Gestão na Universidade Beira Interior (UBI). E-mail: jjmf@ubi.pt

d Doutor em Engenharia de Produção pela Universidade Federal do Rio de Janeiro (UFRJ). Professor do Departamento de Engenharia de Produção da Universidade Federal Fluminense (UFF). E-mail: quelhas@latec.uff.br

e Professor do Departamento de Engenharia de Produção da Universidade Federal Fluminense (UFF). E-mail: gilson@latec.uff.br 
Ronnie J-Figueiredo, Júlio Vieira Neto, João J.M. Ferreira, Osvaldo Luiz Gonçalves Quelhas, Gilson Brito Alves Lima

Knowledge creation and knowledge transfer: an perspective under the kibs vision for evaluating the innovative capacity

Descriptors: KIBS. Knowledge Creation. Knowledge Transfer. Innovation.

\section{INTRODUÇÃO}

Since the initial study by Miles et al. (1995), an increasing number of contributions have questioned the traditional view of service companies as incapable of creating innovations. Researchers and practitioners recognize that far from being innovative latecomers or just intensive generators of technologies and novelties in manufacturing, services are becoming an important option for innovative companies (HOWELLS, 2000; TETHER; METCALFE, 2004).

Although having grown very fast since the 1970s, it is more and more acknowledged that Knowledge Intensive Business Services (KIBS) are essential constituents of service innovation systems (COOKE; LEYDESDORFF, 2006) and are responsible for knowledge transmission (DEN HERTOG, 2000; MULLER; ZENKER, 2001; MILES, 2008).

In this article we share the view of researchers who have, in recent years, investigated the subject KIBS, known in the international literature as Knowledge Intensive Business Services. In 17 years of publications, we have identified articles on this topic, based on a bibliometric analysis carried out in the databases Scopus and ISI Web of Knowledge (Web of Science), from the first publication in 2001 until 2017.

In addition, we have explored the published papers in order to propose a conceptual model for evaluating KIBS' innovative capacity in the service sector. We noticed that, over time, the role of KIBS in the learning-based economy has received increasing attention, from empirical studies that were conducted and classified according to the region, topic and main conclusions (DOLOREUX; LAPERRIĖRE, 2013), which allowed us to carry out this research.

By assessing these articles on KIBS, we found a gap regarding the innovative capacity of service firms. Therefore, we sought to explain how the elements of a conceptual model - with the dimensions KIBS, knowledge creation, knowledge transfer and innovation - can be applied in an integrated way to evaluate the innovative capacity of firms in the service sector. At the end, we 
Ronnie J-Figueiredo, Júlio Vieira Neto, João J.M. Ferreira, Osvaldo Luiz Gonçalves Quelhas, Gilson Brito Alves Lima

Knowledge creation and knowledge transfer: an perspective under the kibs vision for evaluating the innovative capacity

present the proposed model for economic development.

\section{THEORETICAL BACKGROUND}

The rapid growth of the service sector can be observed in developed countries, and especially in emerging countries such as China, India and Brazil. In the former, both the percentages of the service sector and of the jobs involved are above $70 \%$ of GDP (HSIEH et al., 2013). In developing countries the proportion of the service sector is growing fast, causing significant changes in the content of services focused on innovation (CHEN; ZHANG, 2009).

As an example, in the post-industrial era innovation is considered a service source crucial for economic growth, with benefits for clients, employees, entrepreneurs, partners, alliances and communities (CHESBROUGH; SPOHRER, 2006). In global markets, with a high rate of competitiveness, organizations are using their resources to render services that increase the perceived value of their offerings, leading to competitive advantage (MATTHYSSENS; VANDENBEMPT; BERGHMAN, 2006), through the transition from product to service, related to the change of focus in the operations with their clients (OLIVA; KALLENBERG, 2003; BRAX, 2005; NEU; BROWN, 2008; JACOB; ULAGA, 2008).

Services are considered to be a significant part of the economy, and innovation is widely viewed as an important driver of companies' growth (GRIFFIN, 1997; AGARWAL; ERRAMILLI; DEV, 2003), as they are increasingly recognized as much more central and relevant for building competitive advantage than suggested in Porter's value chain (CHESBROUGH, 2011). Manufacturing and product systems are becoming less and less dominant nowadays, being replaced by creation processes of tangible value (CHESBROUGH; SPOHRER, 2006; IfM; IBM, 2008). Services are considered as procedures, performance or activities that change the user's status or meet the consumer's needs, in which production (creation) and use (transfer) occur simultaneously, and the product is considered as the only carrier for services - Service-Dominant Logic (VARGO; LUSCH, 2004). 
Ronnie J-Figueiredo, Júlio Vieira Neto, João J.M. Ferreira, Osvaldo Luiz Gonçalves Quelhas, Gilson Brito Alves Lima

Knowledge creation and knowledge transfer: an perspective under the kibs vision for evaluating the innovative capacity

The evolution of service innovation marked the emergence of the Knowledge-Intensive Services (KIS), especially the Knowledge-Intensive Business Services (KIBS), as a fundamental element of the innovation system (WINDRUM; TOMLINSON, 1999). KIBS favor the modernization of a country's knowledge base through the use of intangible aspects (know-how, software, research, etc.). These, in turn, have become key drivers for value creation and can play several roles in making innovation systems more dynamic and with a better performance, such as knowledge disseminators, customers (especially in relation to other KIBS), knowledge managers, training institutes - usually young and highly trained professionals start early in companies; and political advisors, implementers and evaluators (HIPP, 1999; DEN HERTOG, 2002).

\section{METHOD}

The choice of data was made according to the international relevance of the databases (Web of Science/ISI and Scopus), by comparing the amount and quality of the publications in order to conduct the bibliometric analysis. Thus, we have identified articles on the topic KIBS related to the innovative capacity in the service sector. Using the keywords (1) Knowledge Creation, (2) Knowledge Transfer, (3) Innovation, and (4) KIBS, and based on the Boolean method "AND" and "OR", we arrived at 366 articles in the databases, in the areas of management, economics and engineering. After the exclusion of repeated papers, we reached the number of 161 articles on KIBS, which were then examined. The main methodological aspects are presented in Table 1.

Table 1- Technical record of the study

\begin{tabular}{|c|c|}
\hline Elements & Complements \\
\hline Period of analysis & $2001-2017$ \\
\hline Searched databases & Scopus and Web of Science/ISI \\
\hline Keywords & 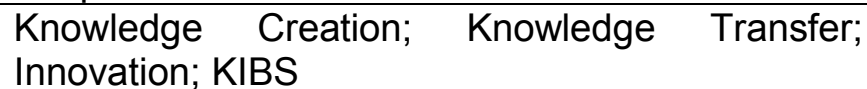 \\
\hline Method & Bibliometrics (Boolean "AND” and "OR") \\
\hline Identified articles & 366 \\
\hline $\begin{array}{r}\text { Articles excluded due to } \\
\text { overlapping }\end{array}$ & 205 \\
\hline
\end{tabular}


Ronnie J-Figueiredo, Júlio Vieira Neto, João J.M. Ferreira, Osvaldo Luiz Gonçalves Quelhas, Gilson Brito Alves Lima

Knowledge creation and knowledge transfer: an perspective under the kibs vision for evaluating the innovative capacity

\begin{tabular}{|l|l|}
\hline Articles analyzed & 161 \\
\hline & Source: Authors.
\end{tabular}

Figure 1 presents the number of articles identified in the two databases, for each year, since 2001.

Figure 1- Evolution of papers on KIBS during the chosen period of study

- Scopus $\quad$ ISI Web of Knowledge

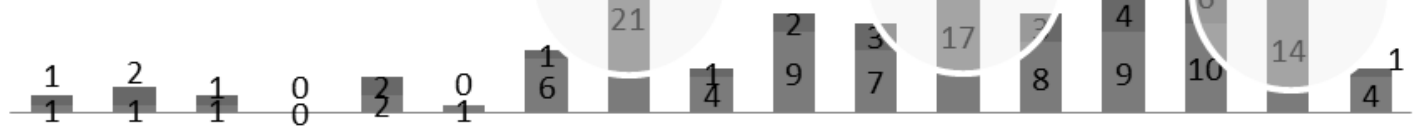

20012002200320042005200620072008200920102011201220132014201520162017

Source: Authors.

Figure 1shows a significant evolution in the year 2007, as compared to the number of papers in 2001 (year of the first publication). These years represent peaks of publications, each corresponding, on average, to 23 articles, approximately $15 \%$ of the published papers. We have considered the periods 2001-2007 (12\%), 2008-2012 (45\%) and 2013-2017 (43\%).

By examining the publication years separately, the highest concentrations were in 2008 - 21 articles found in Scopus database -, 2012 - 26 articles published, from which 17 were in Scopus database and 9 in ISI -, and 2016, with 24 papers identified - 14 in Scopus and 10 in ISI. It should be noted that KIBS has only recently become a topic of interest and discussion, confirmed by the increasing number of articles in the last 10 years, which include $88 \%$ of the publications examined since 2001.

Regarding the most cited articles in the period of highest concentration on the KIBS theme, we used the $h-b$ index and the $m$ index, proposed by Banks (2006) as an extension of Hirsch's h-index (2005). To obtain the h-b index, we considered the number of citations of articles related to that topic in the 17-year period, listed in descending order of citations, totaling the first 10 . For the analysis of the $\mathrm{m}$ index, we used Bank's (2006) definitions evidenced in Table 1, dividing the $h-b$ index by the period of years over which information was needed $(n)$, being considered "hot topics" those with an index $\mathrm{m}>2$, as shown in Table 2. 
Ronnie J-Figueiredo, Júlio Vieira Neto, João J.M. Ferreira, Osvaldo Luiz Gonçalves Quelhas, Gilson Brito Alves Lima

Knowledge creation and knowledge transfer: an perspective under the kibs vision for evaluating the innovative capacity

Table 2- Most cited articles identified upon analysis

\begin{tabular}{|c|c|c|c|}
\hline Author & Article & $\begin{array}{l}\text { h-b } \\
\text { Index }\end{array}$ & $\begin{array}{l}\mathbf{m} \\
\text { Inde } \\
\mathbf{x}\end{array}$ \\
\hline $\begin{array}{l}\text { Muller, E., } \\
\text { Zenker, A. }\end{array}$ & $\begin{array}{l}\text { Business services as actors of knowledge } \\
\text { transformation: The role of KIBS in regional and } \\
\text { national innovation systems (2001). Research } \\
\text { Policy, 30(9), 1501-1516 }\end{array}$ & 58 & 3,41 \\
\hline Den Hertog, P. & $\begin{array}{l}\text { Knowledge-intensive business services as co- } \\
\text { producers of innovation (2000). International } \\
\text { Journal of Innovation Management, } 4 \text { (4), 491- } \\
528\end{array}$ & 47 & 2,76 \\
\hline Miles, I. & $\begin{array}{l}\text { Knowledge intensive business services: } \\
\text { Prospects and policies (2005). Foresight, } 7(6) \text {, } \\
39-63\end{array}$ & 20 & 1,18 \\
\hline $\begin{array}{r}\text { Bettencourt, L. } \\
\text { A., Ostrom, A. } \\
\text { L., Brown, S. } \\
\text { W., Roundtree, } \\
\text { R. I. }\end{array}$ & $\begin{array}{l}\text { Client co-production in knowledge-intensive } \\
\text { business services }(2002) \text {. California } \\
\text { Management Review, 44(4), 100-128 }\end{array}$ & 20 & 1,18 \\
\hline Freel, M. & $\begin{array}{l}\text { Patterns of technological innovation in } \\
\text { knowledge-intensive business services (2006). } \\
\text { Industry and Innovation, } 13(3) \text {, 335-358 }\end{array}$ & 15 & 0,88 \\
\hline $\begin{array}{l}\text { Simmie, J., } \\
\text { Strambach, S. }\end{array}$ & $\begin{array}{l}\text { The contribution of KIBS to innovation in cities: } \\
\text { An evolutionary and institutional perspective } \\
\text { (2006). Journal of Knowledge Management, } \\
\text { 10(5), 26-40 }\end{array}$ & 13 & 0,76 \\
\hline $\begin{array}{l}\text { Cohen, W. M., } \\
\text { Levinthal, D. A. }\end{array}$ & $\begin{array}{l}\text { Absorptive capacity: A new perspective on } \\
\text { learning and innovation (1990). Administrative } \\
\text { Science Quarterly, 35(1),128-152 }\end{array}$ & 11 & 0,65 \\
\hline Drejer, I. & $\begin{array}{l}\text { Identifying innovation in surveys of services: A } \\
\text { Schumpeterian perspective (2004). Research } \\
\text { Policy, 33(3), 551-562 }\end{array}$ & 11 & 0,65 \\
\hline $\begin{array}{l}\text { Gallouj, F., } \\
\text { Weinstein, O. }\end{array}$ & $\begin{array}{l}\text { Innovation in services (1997). Research Policy, } \\
26(4-5), 537-556\end{array}$ & 11 & 0,65 \\
\hline $\begin{array}{l}\text { Muller, E., } \\
\text { Doloreux, D. }\end{array}$ & $\begin{array}{l}\text { What we should know about knowledge- } \\
\text { intensive business services (2009). Technology } \\
\text { in Society, 31(1), 64-72 }\end{array}$ & 11 & 0,65 \\
\hline
\end{tabular}

Source: Authors.

\section{CHARACTERIZATION OF THE DIMENSIONS OF THE CONCEPTUAL MODEL FOR EVALUATING INNOVATIVE CAPACITY}

According to an initial review of the literature on the service sector, KIBS are considered key factors for value creation in organizations, and play several distinct roles to make the innovation system more dynamic and competitive. 
Ronnie J-Figueiredo, Júlio Vieira Neto, João J.M. Ferreira, Osvaldo Luiz Gonçalves Quelhas, Gilson Brito Alves Lima

Knowledge creation and knowledge transfer: an perspective under the kibs vision for evaluating the innovative capacity

Considering previous studies on KIBS, we have conceived a conceptual model on the dynamics of KIBS' innovative capacity in the service sector, with the following dimensions: (i) KIBS (firms); (ii) knowledge creation; (iii) knowledge transfer, and (iv) innovation, as presented in Table 3.

Table 3- Dimensions and Variables

\begin{tabular}{|c|c|c|c|c|c|c|}
\hline \multirow{2}{*}{$\begin{array}{l}\text { KIBS Dimension } \\
\text { KIBS are understood as complex } \\
\text { operations where human capital is the } \\
\text { dominant production factor and main } \\
\text { value added in the development of } \\
\text { customized businesses. }\end{array}$} & \multicolumn{6}{|c|}{ Variables } \\
\hline & $\begin{array}{l}\stackrel{D}{N} \\
\stackrel{E}{=} \\
i=\end{array}$ & 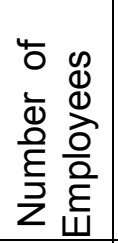 & 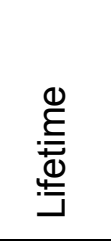 & 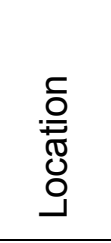 & 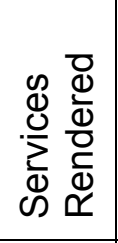 & 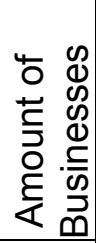 \\
\hline $\begin{array}{l}\text { Miles et al. (1995); Martinez-Fernandez \& } \\
\text { Miles (2006) }\end{array}$ & $x$ & $\times$ & $\times$ & & & $x$ \\
\hline $\begin{array}{l}\text { Hoffman (2009); Conceição (2007); Den } \\
\text { Hertog (2000); Miles et al. (1995) }\end{array}$ & $\times$ & & $\times$ & $\times$ & $\times$ & \\
\hline $\begin{array}{l}5 \text { Tether (2005); Camacho \& Rodriguez } \\
\text { (2008); Naranjo-Valencia, Jimenez- } \\
\text { Jimenez, \& Sanz-Valle (2011); Zortea- } \\
\text { Johnston, Darroch, \& Matear (2011) }\end{array}$ & $\times$ & $\times$ & $\times$ & & & $x$ \\
\hline Knowledge Creation Dimension & \multicolumn{6}{|c|}{ Variables } \\
\hline $\begin{array}{l}\text { Knowledge creation is understood as an } \\
\text { action in which participants have to be } \\
\text { encouraged to actively interact by } \\
\text { creating new applications from existing } \\
\text { knowledge or by exploiting unused } \\
\text { potentialities. }\end{array}$ & 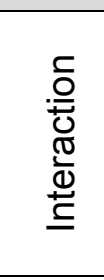 & $\begin{array}{l}\frac{0}{0} \\
\frac{0}{0} \\
\frac{\pi}{0}\end{array}$ & 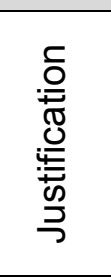 & $\begin{array}{l}\frac{0}{0} \frac{c}{0} \\
\frac{\mathbb{D}}{\Phi} \\
\stackrel{0}{\frac{0}{0}} \\
\text { के } \frac{0}{2}\end{array}$ & $\frac{.}{\frac{0}{n}}$ & \\
\hline Krogh, Ichijo \& Nonaka (2001) & $x$ & $x$ & $x$ & & $x$ & \\
\hline Davenport \& Prusak (2001) & & & & $x$ & & \\
\hline Knowledge Transfer Dimension & \multicolumn{6}{|c|}{ Variables } \\
\hline $\begin{array}{l}\text { Knowledge transfer is understood as the } \\
\text { generation and exchange of new ideas } \\
\text { and concepts, thus creating a process of } \\
\text { different stages, a significant action. }\end{array}$ & 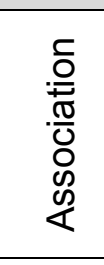 & 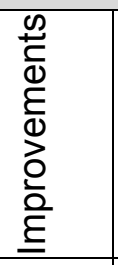 & 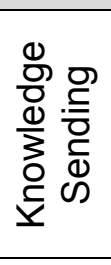 & 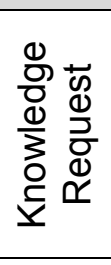 & & \\
\hline Sabbag (2007) & $\times$ & & & $\times$ & & \\
\hline Holsapple \& Joshi, 1999 (pp. 7) & & $\times$ & $x$ & & & \\
\hline Innovation Dimension & \multicolumn{6}{|c|}{ Variables } \\
\hline
\end{tabular}


Ronnie J-Figueiredo, Júlio Vieira Neto, João J.M. Ferreira, Osvaldo Luiz Gonçalves Quelhas, Gilson Brito Alves Lima

Knowledge creation and knowledge transfer: an perspective under the kibs vision for evaluating the innovative capacity

\begin{tabular}{|c|c|c|c|c|c|c|}
\hline $\begin{array}{l}\text { Innovation is understood as a continuous } \\
\text { process of support to companies by } \\
\text { providing intensive knowledge for } \\
\text { customization of solutions, quality } \\
\text { improvement and value generation. A set } \\
\text { of innovative behaviors and activities that } \\
\text { bring economic and social earnings. }\end{array}$ & 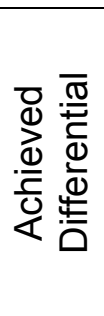 & 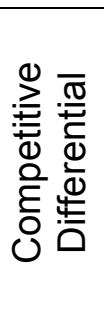 & 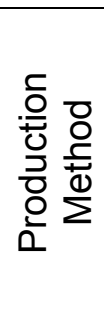 & 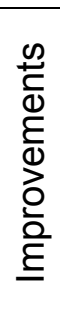 & 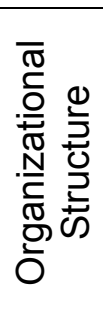 & $\begin{array}{l}\overline{\mathbb{V}} \\
\frac{.}{0} \\
\frac{0}{0} \\
\stackrel{0}{E} \\
\frac{1}{0} \\
\stackrel{0}{-}\end{array}$ \\
\hline $\begin{array}{l}\text { Nählinder (2002); Wood (2002); Freeman } \\
\text { (1988); }\end{array}$ & $\times$ & & & $\times$ & $\times$ & \\
\hline $\begin{array}{l}\text { Damanpour \& Evan (1984); Kimberly \& } \\
\text { Evanisko (1981) }\end{array}$ & & $\times$ & $x$ & & & \\
\hline Knight (1967); Damanpour (1991) & $\times$ & $\times$ & & $\times$ & & $x$ \\
\hline
\end{tabular}

Source: Authors.

\section{KIBS DIMENSION}

According to Den Hertog (2000), KIBS are defined as organizations or private companies that frequently use professional knowledge, whether related to a specific discipline (technique) or domain (technical), generating intermediary knowledge businesses (products or services). In the view of Miles et al. (1995), Boden and Miles (2000), Tomlinson (2002), Nahlinder (2002), CRIC (2004), and Miles (2005), KIBS are defined as a group of companies that find solutions for other companies, based on specific knowledge. Miles et al. (1995), Den Hertog and Bilderbeek (1998), Hipp (2000), André, Feio and Ferrão (2002), and Miles (2007) consider KIBS as agents of dissemination and transfer of knowledge and innovation to their customers, which cannot be dissociated from the nationalregional economic and social environment (macro and micro).

Bettencourt et al. (2002, pp. 100-101) defined KIBS as "companies whose primary value-added activities consist in the accumulation, creation, or dissemination of knowledge with the goal of developing a customized service or product solution to meet customer's needs." Den Hertog and Bilderbeek (1998) highlight some important aspects of KIBS, such as: catalysts in the creation of processes of knowledge and innovation for their customers' companies; knowledge can be created by them or developed in cooperation with their clients; they play a role that enables processes of knowledge conversion, helping their customers to become learning organizations; intervention is mainly an oriented process, non-contractual, and implies the use of tacit knowledge. 
Ronnie J-Figueiredo, Júlio Vieira Neto, João J.M. Ferreira, Osvaldo Luiz Gonçalves Quelhas, Gilson Brito Alves Lima

Knowledge creation and knowledge transfer: an perspective under the kibs vision for evaluating the innovative capacity

KIBS possess qualities that are highlighted by Miles et al. (1995): i) they contribute to knowledge and innovation in the economy; ii) they serve as knowledge carriers; iii) they favor the development of new activities for clients; iv) they collaborate to build new knowledge in their products; and v) they facilitate flows of knowledge and expertise from one sector to another (BODEN; MILES, 2000; TOMLINSON, 2000; CRIC, 2004; MULLER; ZENKER, 2001). The proposed variables are shown in Table 4.

\section{Table 4 - Variables and Definitions}

\begin{tabular}{|c|c|}
\hline Variable & Definition \\
\hline Firm Size & $\begin{array}{l}\text { For firm's size we adopted IBGE's (Brazilian Institute of Geography and } \\
\text { Statistics, 2010) criteria, which consider micro enterprise the one with an } \\
\text { annual revenue below or equal to } R \$ 2.4 \text { million (approximately US\$ } \\
730,000) \text {; small enterprise, with a revenue above } R \$ 2.4 \text { million and } \\
\text { below } R \$ 16 \text { million ( } \sim \text { US } \$ 4,850 \text { million); medium enterprise, above } R \$ \\
16 \text { million and below or equal to } R \$ 90 \text { million ( } \sim \text { US } \$ 27 \text { million); } \\
\text { medium-large, above } R \$ 90 \text { million and below or equal } R \$ 300 \text { million ( } \\
\text { US } \$ 91 \text { million); and large, with an annual revenue above } R \$ 300 \text { million. }\end{array}$ \\
\hline $\begin{array}{r}\begin{array}{r}\text { Number } \\
\text { of } \\
\text { Employees }\end{array}\end{array}$ & $\begin{array}{l}\text { The number of employees in the firm considers the amount of people } \\
\text { who have a work permit, according to the Brazilian law CLT, measured } \\
\text { in five echelons: (1) up to } 10 \text { employees; (2) up to } 30 \text { employees; ( } 3 \text { ) } \\
\text { up to } 50 \text { employees; (4) up to } 100 \text { employees; and (5) above } 100 \\
\text { employees. }\end{array}$ \\
\hline Lifetime & $\begin{array}{l}\text { Firm's lifetime is measured from its foundation year, divided in five } \\
\text { echelons: (1) up to } 10 \text { years; (2) from } 11 \text { to } 30 \text { years; ( } 3 \text { ) from } 31 \text { to } 50 \\
\text { years; (4) from } 51 \text { to } 100 \text { years; and (5) above } 100 \text { years. }\end{array}$ \\
\hline Location & $\begin{array}{l}\text { Four capitals from Brazil southeast region made part of the sample, } \\
\text { and received codes from } 1 \text { to } 4 \text {, in ascending order: (1) São Paulo/SP; } \\
\text { (2) Rio de Janeiro/RJ; (3) Belo Horizonte/MG; and (4) Vitória/ES. }\end{array}$ \\
\hline $\begin{array}{r}\text { Number } \\
\text { of } \\
\text { ventures } \\
\text { created }\end{array}$ & $\begin{array}{l}\text { The amount of ventures created in the last five years was measured } \\
\text { according to five echelons: (1) up to } 10 \text { ventures; (2) up to } 30 \text { ventures; } \\
\text { (3) up to } 50 \text { ventures; (4) up to } 100 \text { ventures; and (5) above } 100 \\
\text { ventures. }\end{array}$ \\
\hline $\begin{array}{r}\text { Type of } \\
\text { service } \\
\text { rendered }\end{array}$ & $\begin{array}{l}\text { We included in the sample firms that belong to } 16 \text { CNAE (National } \\
\text { Classification of Economic Activities) and NACE (Nomenclature } \\
\text { statistique des Activités économiques dans la Communauté } \\
\text { Européenne), which are: (1) telecommunications; (2) computer } \\
\text { systems consulting; (3) development of software programs; (4) data } \\
\text { processing; (5) database activities; (6)technical services to firms; (7) } \\
\text { legal activities; (8) maintenance and repair of office and informatics } \\
\text { equipment; (9) accounting and auditing; (10) market research and } \\
\text { opinion poll; (11) management of equity interest; (12) business } \\
\text { management consulting; (13) architecture and engineering services } \\
\text { and specialized technical assistance; (14) materials and products } \\
\text { tests; (15) advertising; and (16) informatics activities. }\end{array}$ \\
\hline
\end{tabular}


Ronnie J-Figueiredo, Júlio Vieira Neto, João J.M. Ferreira, Osvaldo Luiz Gonçalves Quelhas, Gilson Brito Alves Lima

Knowledge creation and knowledge transfer: an perspective under the kibs vision for evaluating the innovative capacity

\subsection{Knowledge Creation Dimension}

The role of knowledge has been widely discussed in the management literature, but when it comes to the "knowledge based economy" - at least to some extent - it holds a different logic from value creation in the industrial economy. The special attributes of knowledge, its dimensions and especially its feature as a "public good", together with the infinite possibilities of its replication, make it a key factor for innovation in the new economy, and is seen today as the main source of competitive advantage (DRUCKER, 1995; MARR, 2005).

Knowledge is presented as a competitive differential and key element in the innovation process (TIDD; BESSANT; PAVITT, 2008; YANG; YU; LEE, 2002), which leads any product - goods or services - to be measured by the amount of knowledge embedded in it, and buyers' perception of its value through technology support (BROWN, 2000), besides sustaining the competitive advantage of an organization, an industry sector or a country (WENHONG; MIN, 2010). "It is the basis of the ability to act and has four fundamental attributes: knowledge is tacit; knowledge is action oriented; knowledge is supported by rules - both conscious and unconscious - that act as filters of knowledge; and knowledge is permanently changing (SVEIBY, 1997, pp. 29-35, 37).

Knowledge is not only restricted to documents, or guides of norms and management manuals, but is also found in the routines, processes and ways of conducting people's work (DAVENPORT; PRUSAK, 2001; SANTIAGO JR, 2004), causing organizations to assume an important role in the discussion on how it can be used to create innovative products, a key element for a firm to achieve competitive advantage (TIDD; BESSANT; PAVITT, 2008; WENHONG; MIN, 2010). The ability to manage knowledge can be a decisive factor for a company to remain competitive in the market (GRANT, 1996; NONAKA; TOYAMA, 2002). Thus, Drucker (1999) defines knowledge management as "the coordination and exploitation of organizational knowledge resources, in order to create benefits and competitive advantage", being more limited in his definition, by considering only lessons learned and techniques used for managing what is already known (WELLMAN, 2009). In this sense and after reviewing the literature 
Ronnie J-Figueiredo, Júlio Vieira Neto, João J.M. Ferreira, Osvaldo Luiz Gonçalves Quelhas, Gilson Brito Alves Lima

Knowledge creation and knowledge transfer: an perspective under the kibs vision for evaluating the innovative capacity

on knowledge creation, we consider in this study the following variables related to the innovative capacity of firms, as shown in Table 5.

Table 5 - Variables and Definitions of Knowledge Creation

\begin{tabular}{|r|l|}
\hline Variable & Definition \\
\hline $\begin{array}{r}\text { Knowledge } \\
\text { creation }\end{array}$ & $\begin{array}{l}\text { Refers to the firm's involvement in knowledge creation in the last five } \\
\text { years. This is a dichotomous variable, which assumes the simple } \\
\text { binary value 0 for firms that did not create knowledge in the period, } \\
\text { and 1 for firms that did. }\end{array}$ \\
\hline Interaction & $\begin{array}{l}\text { It considers the relationship between people through the use of } \\
\text { dialogue, ranked in five echelons: (1) very low importance; (2) low } \\
\text { importance; (3) medium importance; (4) high importance; and (5) very } \\
\text { high importance. }\end{array}$ \\
\hline Dialogue & $\begin{array}{l}\text { It considers dialogue as a continuous reflection on the business, } \\
\text { ranked in five echelons: (1) very low importance; (2) low importance; } \\
\text { (3) medium importance; (4) high importance; and (5) very high } \\
\text { importance. }\end{array}$ \\
\hline Justification & $\begin{array}{l}\text { Justification of the concepts created from the dialogue, ranked in five } \\
\text { echelons: (1) very low importance; (2) low importance; (3) medium } \\
\text { importance; (4) high importance; and (5) very high importance. }\end{array}$ \\
\hline Systemic & $\begin{array}{l}\text { The development of a model from the concepts created through } \\
\text { dialogue, ranked in five echelons: (1) very low importance; (2) low } \\
\text { importance; (3) medium importance; (4) high importance; and (5) very } \\
\text { high importance. }\end{array}$ \\
\hline Diffusion & $\begin{array}{l}\text { The diffusion of knowledge created to those interested in the } \\
\text { business, ranked in five echelons: (1) very low importance; (2) low } \\
\text { importance; (3) medium importance; (4) high importance; and (5) very } \\
\text { high importance. }\end{array}$ \\
\hline
\end{tabular}

Source: Authors.

\subsection{KNOWLedge TRANSFER Dimension}

For some authors, knowledge sharing differs from knowledge transfer, being defined as a more useful concept, and seen as a double process of research and contribution to knowledge, through activities such as learning by observation, listening and asking, sharing ideas, giving advice, recognizing clues, and adopting patterns of behavior. Hendriks (1999, pp. 22) states that "it takes knowledge to get knowledge and thus, share knowledge." Knowledge sharing is an activity both individual and collective, involving explicit and tacit exchanges between people (POLANYI, 1966). For Geraghty and Desouza (2005), knowledge transfer is defined as the act of transmitting from one entity to another, 
Ronnie J-Figueiredo, Júlio Vieira Neto, João J.M. Ferreira, Osvaldo Luiz Gonçalves Quelhas, Gilson Brito Alves Lima

Knowledge creation and knowledge transfer: an perspective under the kibs vision for evaluating the innovative capacity

in an optimal and reliable way, a social process by which one member is affected by the experience of another through social learning (HANSEN, 1999; ARGOTE; INGRAM, 2000), and it may involve a wide diversity of technological knowledge, from the most basic to the most specific procedures and capacities (AMESSE; COHENDET, 2001).

Nonaka and Takeuchi (1995), Damsgaard and Scheepers (2001) and Lakomski (2003) state that sharing knowledge involves the generation and exchange of new ideas and concepts, often with a significant action - for example, solutions for a problem. In this reciprocal process, receivers and creators exchange knowledge through conversations, online forums etc., making use and contributing to knowledge-based artifacts that are relevant to a specific context. Bartol and Srivastava (2002) define knowledge transfer as the sharing of information, ideas, suggestions and organizationally relevant experiences, from the individual to others. Szulanski (2000) approaches the transfer of knowledge by emphasizing that this transference should not be seen as an act in which one person passes something to another, but as a process, made of different stages, each with its own difficulties. In this sense, and after reviewing the literature on knowledge transfer, we consider in this study the following variables related to the innovative capacity of firms, as presented in Table 6 .

Table 6 - Variables and Definitions of Knowledge Transfer

\begin{tabular}{|c|c|}
\hline Variable & Definition \\
\hline $\begin{array}{r}\text { Knowledge } \\
\text { Transfer }\end{array}$ & $\begin{array}{l}\text { The involvement of the firm in knowledge transfer in the last five } \\
\text { years. This is a dichotomous variable, which assumes the simple } \\
\text { binary value } 0 \text { for firms that did not transfer knowledge in the period, } \\
\text { and } 1 \text { for firms that did. }\end{array}$ \\
\hline Association & $\begin{array}{l}\text { It considers the free association of ideas, which generates others } \\
\text { as a result, and is ranked in five echelons: (1) very low importance; } \\
\text { (2) low importance; (3) medium importance; (4) high importance; } \\
\text { and (5) very high importance. }\end{array}$ \\
\hline Improvement & $\begin{array}{l}\text { It is obtained by considering the test of collective ideas in a coherent } \\
\text { form, and is ranked in five echelons: (1) very low importance; }(2) \\
\text { low importance; (3) medium importance; (4) high importance; and } \\
\text { (5) very high importance. }\end{array}$ \\
\hline $\begin{array}{r}\text { Knowledge } \\
\text { sending }\end{array}$ & $\begin{array}{l}\text { The remittance of knowledge by the firm without a formal request } \\
\text { from the client, ranked in five echelons: (1) very low importance; (2) } \\
\text { low importance; (3) medium importance; (4) high importance; and } \\
\text { (5) very high importance. }\end{array}$ \\
\hline
\end{tabular}

Inf. Inf., Londrina, v. 24, n. 1, p. 300 - 325, jan./abr. 2019. 
Ronnie J-Figueiredo, Júlio Vieira Neto, João J.M. Ferreira, Osvaldo Luiz Gonçalves Quelhas, Gilson Brito Alves Lima

Knowledge creation and knowledge transfer: an perspective under the kibs vision for evaluating the innovative capacity

\begin{tabular}{|c|l|}
\hline $\begin{array}{r}\text { Knowledge } \\
\text { request }\end{array}$ & $\begin{array}{l}\text { The formal request of knowledge by the customer, ranked in five } \\
\text { echelons: (1) very low importance; (2) low importance; (3) medium } \\
\text { importance; (4) high importance; and (5) very high importance. }\end{array}$ \\
\hline
\end{tabular}

Source: Author.

\subsection{INNOVATION DIMENSION}

Innovation can be defined as an idea, practice, or a material good that is perceived as new and of relevant application (ZALTMAN; DUNCAN; HOLBEK, 1973); or an object perceived as new by an individual or an organization (ROGERS, 2003), and considered, from a business point of view, as the key to economic growth, competitive advantage, and even the survival of companies (AGARWAL et al., 2003; MERRILEES; RUNDLE-THIELE; LYE, 2011; SHEEHAN, 2006). In the process of implementing an innovation, the nature of information exchange in the relationships determines the conditions under which an employee receives knowledge or has an experience by using the new idea (ENZ, 2012).

The term "innovation" has taken a broader meaning in recent years. More than the development of new products in companies, it is also the creation of new arrangements between the institutional spheres that provide the conditions for innovation" (ETZKOWITZ, 2003, pp. 299). A process that combines problems and needs with solutions that are relevant and new for these problems (WAHREN, 2004; RICKARDS, 1985; PATON; MCLAUGHLIN, 2008; KERKA; KRIEGSMANN; SCHWERING, 2009). It can be understood, in a general way, as the apprehension and introduction of new practices, products, processes and designs by companies and institutions, that is, the result of a process that can only be analyzed when considering its interactive character (SBICCA; PELAEZ, 2006).

A search, discovery, experimentation, development, imitation and adoption of new products, processes and new organizational techniques, that should be something absolutely new in the world, focused on the economic agent that is implementing it in the organization (DOSI et al., 1988). In this sense, and after reviewing the literature on innovation in services, we consider in this study 
Ronnie J-Figueiredo, Júlio Vieira Neto, João J.M. Ferreira, Osvaldo Luiz Gonçalves Quelhas, Gilson Brito Alves Lima

Knowledge creation and knowledge transfer: an perspective under the kibs vision for evaluating the innovative capacity

the following variables related to the innovative capacity of firms, as shown in Table 7.

\section{Table 7- Variables and Definitions of Innovation}

\begin{tabular}{|c|c|}
\hline Variable & Definition \\
\hline Innovation & $\begin{array}{l}\text { Refers to the involvement of the firm in innovation in the last five } \\
\text { years. This is a dichotomous variable, which assumes the simple } \\
\text { binary value } 0 \text { for firms that did not innovate in the period, and } 1 \\
\text { for firms that did. }\end{array}$ \\
\hline $\begin{array}{r}\text { Achieved } \\
\text { Differential }\end{array}$ & $\begin{array}{l}\text { The introduction of a new differentiated product in the business, } \\
\text { ranked in five echelons: (1) very low importance; ( } 2 \text { ) low } \\
\text { importance; (3) medium importance; (4) high importance; and (5) } \\
\text { very high importance. }\end{array}$ \\
\hline $\begin{array}{r}\text { Competitive } \\
\text { Differential }\end{array}$ & $\begin{array}{l}\text { The introduction of a new process in the business, ranked in five } \\
\text { echelons: (1) very low importance; (2) low importance; ( } 3) \\
\text { medium importance; (4) high importance; and (5) very high } \\
\text { importance. }\end{array}$ \\
\hline $\begin{array}{r}\text { Form of } \\
\text { production }\end{array}$ & $\begin{array}{l}\text { The introduction of a new form of production, product or process } \\
\text { in the business, ranked in five echelons: (1) very low importance; } \\
\text { (2) low importance; (3) medium importance; (4) high importance; } \\
\text { and (5) very high importance. }\end{array}$ \\
\hline Improvements & $\begin{array}{l}\text { The introduction of process, product or organizational } \\
\text { improvements in the business, ranked in five echelons: (1) very } \\
\text { low importance; (2) low importance; (3) medium importance; (4) } \\
\text { high importance; and (5) very high importance. }\end{array}$ \\
\hline $\begin{array}{r}\text { Organizational } \\
\text { Structure }\end{array}$ & $\begin{array}{l}\text { The implementation of a new structure in the organization, } \\
\text { ranked in five echelons: (1) very low importance; ( } 2 \text { ) low } \\
\text { importance; (3) medium importance; (4) high importance; and (5) } \\
\text { very high importance. }\end{array}$ \\
\hline Technological & $\begin{array}{l}\text { The launching of a new technological production process of } \\
\text { products and services, ranked in five echelons: (1) very low } \\
\text { importance; (2) low importance; (3) medium importance; (4) high } \\
\text { importance; and (5) very high importance. }\end{array}$ \\
\hline
\end{tabular}

Source: Author.

\section{THE DYNAMICS OF INNOVATIVE CAPACITY IN THE PROPOSED MODEL}

The new phase of the economy is based on a productive system that demands a new pattern of competition from companies, focusing their strategies on the development of innovative capacity, which is essential to take part in the information and knowledge flows that distinguish the current phase of world capitalism (CASTELLS, 1997). In terms of innovative capacity, knowledge and innovation are considered the main factors that define the competitiveness and development of nations, regions, sectors, companies and even individuals 
Ronnie J-Figueiredo, Júlio Vieira Neto, João J.M. Ferreira, Osvaldo Luiz Gonçalves Quelhas, Gilson Brito Alves Lima

Knowledge creation and knowledge transfer: an perspective under the kibs vision for evaluating the innovative capacity

(CASSIOLATO; LASTRES, 1999).

There is a perception that companies must make upgrading, improving their abilities, to move to economic niches more profitable and/or intensive in skills and technology (GEREFFI, 1999). They also need to learn faster and faster, absorbing different knowledge previously acquired, through continuous interaction with several agents in social, political and institutional contexts, thus establishing an innovative process.

Santos (2007) sees the innovative process as the search for learning, which depends on constant interactions so that different knowledge (tacit and codified), information and experiences can be shared, and by adding up one upon another, result in more innovations. In this context, companies demand increasing international competition, by introducing technology and communication associated with the strategy of developing innovative capacity in businesses. This approach promotes their competitive advantage through the dynamics of learning - knowledge creation and transfer - daily, informally transferring or assimilating it, along with creativity, as a continuous process (AUN; CARVALHO; KROEFF, 2005).

In the conceptual model proposed in this study, the dynamics of innovative capacity refers to the relationship between the dimensions KIBS (companies), knowledge creation, knowledge transfer and innovation, in the service sector. Regarding the efficiency of the innovative capacity dynamics, it evaluates the relationship between knowledge creation and knowledge transfer. Hence, it can measure how much of the knowledge created was transferred to the business. Next, it can validate the efficiency of the innovative capacity dynamics through the amount of innovations generated in the business, by relating the creation of knowledge with the transfer of knowledge and innovation. Subsequently, it can measure how much innovation and of which kind has contributed to economic gains in the business, in addition to competitive advantage. Figure 2 presents the proposed conceptual model for assessing the innovative capacity of KIBS in the service sector. 
Figure 2 - Conceptual Model for assessing the innovative capacity of service firms

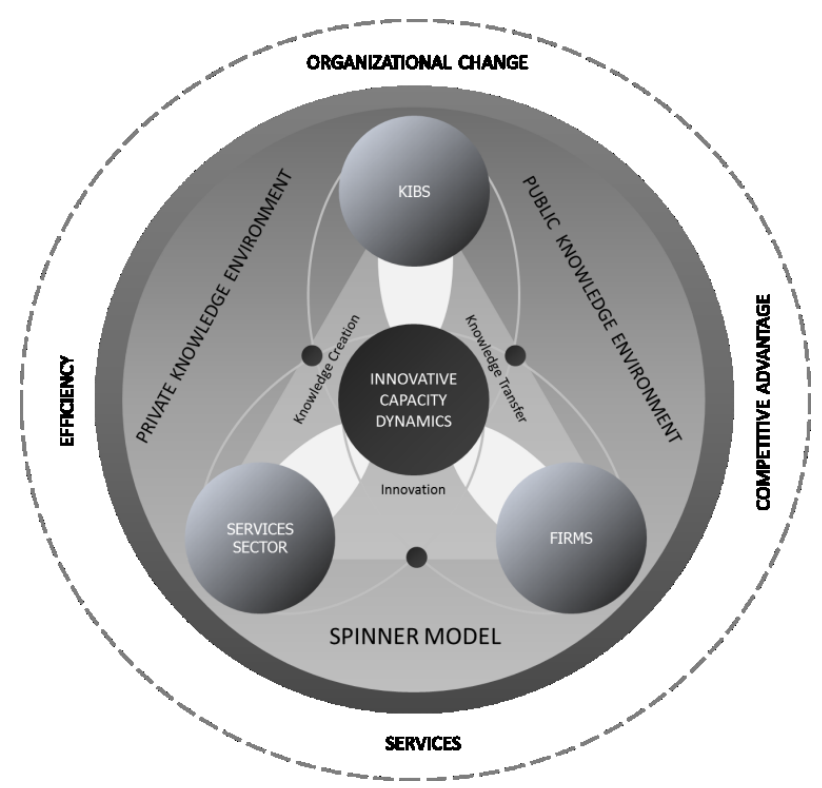

Source: Authors.

The proposed model originates from KIBS, firms that provide knowledge intensive services in the service sector, which aim to create and/or transfer knowledge to companies in other sectors, either through a professional or technological approach, leading to innovation and consequently to increased competitiveness. The assessment of KIBS innovative capacity in the service sector refers to the relationship between KIBS and the service sector, where their dynamic factors, as knowledge creation and transfer, will be associated to the demands of the service providers attended by KIBS. We understand that the integration of knowledge and its transfer can foster a firm's competitive advantage through innovation generated by the intensive use of knowledge.

This approach occurs within the scope of public knowledge, and interacts with KIBS' private environment. Therefore, the relationship promotes the beginning of organizational change, when one of the companies served by KIBS shows an increase in competitiveness due to the efficient use of knowledge. Efficiency is analyzed by measuring knowledge creation or transfer. So does its relationship with firm's innovation.

The dynamics of KIBS' innovative capacity will be measured in private knowledge environments, originated from KIBS, and public knowledge 
Ronnie J-Figueiredo, Júlio Vieira Neto, João J.M. Ferreira, Osvaldo Luiz Gonçalves Quelhas, Gilson Brito Alves Lima

Knowledge creation and knowledge transfer: an perspective under the kibs vision for evaluating the innovative capacity

environments, in companies served by KIBS for the provision of knowledge intensive services, called organizational transformation environment.

\section{RESULTS AND CONCLUSION}

In this study, bibliometric analysis showed the evolution of the theme and the authors of papers with the highest number of citations on the topic. We note that the articles do not have a direct relationship with the evaluation of innovative capacity. The greater concentration of the analyzed papers investigates the attributes and roles of KIBS for innovation. Among the papers identified with the h-b index, two "hot topics" stand out, measured by the $m$ index, whose authors are Muller, E. and Zenker, A. (2001), and Den Hertog, P. (2000). Therefore, KIBS can be interpreted in several ways, but an issue is very clear, regardless of a single concept, that is, its purpose: to contribute to companies' innovation. There is an evolution of the topic in the literature and an opportunity to assess the innovative capacity of KIBS in the service sector, which was the object of this study.

\section{REFERENCES}

AGARWAL, S.; ERRAMILLI, M. K.; DEV, C. S. Market orientation and performance in service firms: role of innovation. Journal of Services Marketing, v. 17, n. 1, p. 68-82, 2003.

AMESSE, F.; COHENDET, P. Technology transfer revisited from the perspective of the knowledge-based economy. Research Policy, v. 30, n. 9, p. 1459-1478, 2001.

ANDRÉ, I.; FEIO, P. A.; FERRÃO, J. Portugal: Knowledge-intensive services and modernization. In: WOOD, P. (Ed.). Consultancy and Innovation: the business service revolution in Europe. London: Routledge, 2002. p. 283-315.

ARGOTE, L.; INGRAM, P. Knowledge Transfer: A Basis for Competitive Advantage in Firms. Organizational Behavior and Human Decision Processes, v. 82, n. 1, p. 150-169, 2000. 
Ronnie J-Figueiredo, Júlio Vieira Neto, João J.M. Ferreira, Osvaldo Luiz Gonçalves Quelhas, Gilson Brito Alves Lima

Knowledge creation and knowledge transfer: an perspective under the kibs vision for evaluating the innovative capacity

AUN, M. P.; CARVALHO, A. M. A.; KROEFF, R. L. Arranjos produtivos locais e sustentabilidade: políticas públicas promotoras de desenvolvimento regional e da inclusão social. Revista Alcance, v. 12, n. 3, p. 317-334, 2005.

BANKS, M. G. An extension of the Hirsch index: Indexing scientific topics and compounds. Scientometrics, v. 69, n. 1, p. 161-168, 2006.

BARTOL, K.; SRIVASTAVA, A. Encouraging knowledge sharing: the role of organizational reward systems. Journal of Leadership \& Organizational Studies, v. 9, n. 1, p. 64-76, 2002.

BETTENCOURT, L. A.; OSTROM, A. L.; BROWN, S. W.; ROUNDTREE, R. I. Client co-production in knowledge intensive business services. California Management Review, v. 44, n. 4, p. 100-128, 2002.

BODEN, M.; MILES, I. Services and Knowledge-Based Economy. London: Continuum, 2000.

BRAX, S. A manufacturer becoming service provider - challenges and a paradox. Managing Service Quality, v. 15, n. 2, p. 142-155, 2005.

BROWN, J. S. The Social Life of Information. Cambridge, MA: Harvard Business Review Press, 2000.

CAMACHO, J. A.; RODRIGUEZ, M. Are KIBS more than intermediate inputs? An examination into their R\&D diffuser role in Europe. International Journal of Services Technology and Management, v. 10, n. 2-4, p. 254-272, 2008.

CASSIOLATO, J. E.; LASTRES, H. Globalização e inovação localizada: experiências de sistemas locais no Mercosul. Brasília: IBICT, 1999.

CASTELLS, M. The Information Age: Economy, society and culture (The power of identity). Cambridge: Blackwell, 1997. v. 2.

CENTER FOR RESEARCH ON INNOVATION AND COMPETITION (CRIC). Defining the role of knowledge-intensive business services in the economy. Manchester: 2004. Available in:

http://www.les1.man.ac.uk/cric/projects/project-6.htm. Access in: 20 nov. 2018.

CHEN, S.; ZHANG, Y. Service Culture and its Impact on Service Innovation: Based on the Model of Service Value Chain. In: PROCEEDINGS OF THE 2009 INTERNATIONAL CONFERENCE ON MANAGEMENT AND SERVICE SCIENCE (MASS 2009), Wuhan University, China. 2009. Available in: http://ieeexplore.ieee.org/abstract/document/5304776/?reload=true. Access in: 20 nov. 2018.

CHESBROUGH, H. W. Open services innovation: Rethinking your business to grow and compete in a new era. San Francisco: Jossey-Bass, 2011. 
Ronnie J-Figueiredo, Júlio Vieira Neto, João J.M. Ferreira, Osvaldo Luiz Gonçalves Quelhas, Gilson Brito Alves Lima

Knowledge creation and knowledge transfer: an perspective under the kibs vision for evaluating the innovative capacity

CHESBROUGH, H. W.; SPOHRER, J. A research manifesto for services science. Communications of the ACM, v. 49, n. 7, p. 35-40, 2006.

COHEN, W.; LEVINTHAL, D. A. Absorptive capacity: A new perspective on learning and innovation. Administrative Science Quarterly, v. 35, n. 1, p. 128152, 1990.

CONCEIÇÃO, O. A. C. Além da transação: uma comparação do pensamento dos institucionalistas com os evolucionários e pós-keynesianos. Economia, v. 7, n. 3, p. 621-642, 2007.

COOKE, P.; LEYDESDORFF, L. Regional development in the knowledgebased economy: the construction of advantage. Journal of Technology Transfer, v. 31, n. 1, p. 5-15, 2006.

DAMANPOUR, F. Organizational innovation: a meta-analysis of effects of determinants and moderators. Academy of Management Journal, v. 34, n. 3, p. 555-590, 1991.

DAMANPOUR, F.; EVAN, W. M. Organizational innovation and performance: the problem of "organizational lag". Administrative Science Quarterly, v. 29, n. 3, p. 392-409, 1984.

DAMSGAARD, J.; SCHEEPERS, R. Harnessing intranet technology for organisational knowledge creation. Australian Journal of Information Systems, v. 9, n. 1, p. 4-15, 2001. (Special Edition on Knowledge Management).

DAVENPORT, T. H.; PRUSAK, L. Conhecimento empresarial: como as organizações gerenciam o seu capital intelectual. Tradução de L. Peres. 3. ed. Rio de Janeiro: Campus, 2001.

DEN HERTOG, P. Knowledge intensive business services as co-producers of innovation. International Journal of Innovation Management, v. 4, n. 4, p. 491-452, 2000.

DEN HERTOG, P. Co-producers of innovation: the role of knowledge-intensive business services in innovation. In: GADREY, J.; GALLOUJ, F. (Ed.)

Productivity, innovation and knowledge in services: New economic and socio-economic approaches. Cheltenham: Edward Elgar, 2002. p. 223-255.

DEN HERTOG, P.; BILDERBEEK, R. Conceptualizing (service) Innovation and the Knowledge Flow between KIBS and their Clients. SI4S Topical paper, 11. Oslo: STEP Group, 1998.

DOLOREUX, D.; LAPERRIĖRE, A. Internationalisation and innovation in the knowledge-intensive business services. Berlin: Springer-Verlag, 2013. 
Ronnie J-Figueiredo, Júlio Vieira Neto, João J.M. Ferreira, Osvaldo Luiz Gonçalves Quelhas, Gilson Brito Alves Lima

Knowledge creation and knowledge transfer: an perspective under the kibs vision for evaluating the innovative capacity

DOSI, G.; FREEMAN, C.; NELSON, R.; SILVERBERG, G.; SOETE, L. (Ed.) Technical Change and Economic Theory. London: Pinter Publishers, 1988.

DREJER, I. Identifying innovation in surveys of services: a Schumpeterian perspective. Research Policy, v. 33, n. 3, p. 551-562, 2004.

DRUCKER, P. F. Managing in a time of great change. New York: Truman Talley Books, 1995.

DRUCKER, P. F. Management challenges for the 21st century. New York: Harper Collins, 1999.

ENZ, C. A. Strategies for the Implementation of Service Innovations. Cornell Hospitality Quarterly, v. 53, n. 3, p. 187-195, 2012.

ETZKOWITZ, H. Innovation in innovation: the triple helix of university-industrygovernment relations. Social Science Information, v. 42, n. 3, p. 293-337, 2003.

FREEL, M. Patterns of technological innovation in knowledge-intensive business services. Industry and Innovation, v. 13, n. 3, p. 335-358, 2006.

FREEMAN, C. Introduction. In: DOSI, G.; FREEMAN, C.; NELSON, R.; SILVERBERG, G.; SOETE, L. (Ed.). Technical Change and Economic Theory. London: Frances Pinter, 1988.

GALLOUJ, F.; WEINSTEIN, O. Innovation in Services. Research Policy, v. 26, n. 4-5, p. 537-556, 1997.

GERAGHTY, K.; DESOUZA, K. C. Optimizing knowledge networks. Industrial Management, v. 47, n. 6, p. 25-30. 2005.

GEREFFI, G. International trade and industrial upgrading in the apparel commodity chain. Journal of International Economics, v. 48, n. 1, p. 37-70, 1999.

GRANT, R. Toward a knowledge-based theory of the firm. Strategic Management Journal, v. 17, p. 109-122, 1996.

GRIFFIN, A. PDMA research on new product development practices: updating trends and benchmarking best practices. Journal of Product Innovation Management, v. 16, n. 4, p. 429-458, 1997.

HANSEN, M. The search-transfer problem: The role of weak ties in sharing knowledge across organization subunits. Administrative Science Quarterly, v. 44, n. 1, p. 82-111, 1999. 
Ronnie J-Figueiredo, Júlio Vieira Neto, João J.M. Ferreira, Osvaldo Luiz Gonçalves Quelhas, Gilson Brito Alves Lima

Knowledge creation and knowledge transfer: an perspective under the kibs vision for evaluating the innovative capacity

HENDRIKS, P. Why share knowledge? The influence of ICT on the motivation for knowledge sharing. Knowledge and process management, v. 6, n. 2, p. 91-100, 1999.

HIPP, C. The role of knowledge-intensive business services in the new mode of knowledge production. Al \& Society, v. 13, n. 1, p. 88-106, 1999.

HIPP, C. Innovationsprozesse im Dientleistungssektor. Eine theoretisch und empirisch basiert Innovationstypologie. Heidelberg: Physica, 2000.

HIRSCH, J. E. An index to quantify an individual's scientific research output. Proceedings of the National Academy of Sciences of the USA, v. 102, $n$. 46, p. 16569-16573, 2005.

HOFFMAN, S. Revisiting Marshall's law: Why does labor's share interact with the elasticity of substitution to decrease the elasticity of labor demand? Journal of Economic Education, v. 40, n. 2, p. 437-445, 2009.

HOLSAPPLE, C.; JOSHI, K. D. Description and analysis of existing knowledge management frameworks. In: PROCEEDINGS OF THE 32 ${ }^{\mathrm{ND}}$ ANNUAL HAWAll INTERNATIONAL CONFERENCE ON SYSTEM SCIENCES, (HICSS-32), Maui, HI, 1999.

HOWELLS, J. Research and Technology Outsourcing and Systems of Innovation. In: METCALFE, J. S.; MILES, I. (Ed.), Innovation Systems in the Service Economy. London: Kluwer, 2000. p. 271-295.

HSIEH, Jung-Kuei; CHIU, Hung-Chang; WEI, Chih-Ping; YEN, H. R.; CHENG, Yu-Chun. A practical perspective on the classification of service innovations.

Journal of Services Marketing, v. 27, n. 5, p. 371-384, 2013.

IFM; IBM. Succeeding through service innovation: A service perspective for Education, Research, Business and Government. Cambridge: University of Cambridge Institute for Manufacturing. 2008.

JACOB, F.; ULAGA, W. The transition from product to service in business markets: an agenda for academic inquiry. Industrial Marketing Management, v. 37, n. 3 , p. $247-253,2008$.

KERKA, F.; KRIEGSMANN, B.; SCHWERING, M. G. Evaluating innovation ideas: a comprehensive approach to new product development. International Journal for Technology Intelligence and Planning, v. 5, n. 2, p. 118-136, 2009.

KIMBERLY, J. R.; EVANISKO, M. J. Organizational innovation: the influence of individual organizational and contextual factors on hospital adoption of technological and administrative innovations. Academy of Management Journal, v. 24, n. 4, p. 689-713, 1981. 
Ronnie J-Figueiredo, Júlio Vieira Neto, João J.M. Ferreira, Osvaldo Luiz Gonçalves Quelhas, Gilson Brito Alves Lima

Knowledge creation and knowledge transfer: an perspective under the kibs vision for evaluating the innovative capacity

KNIGHT, K. E. A descriptive model of intra-firm innovation process. The Journal of Business, v. 40, n. 4, p. 478-496, 1967.

KROGH, G. V.; ICHIJO, K.; NONAKA, I. Facilitando a criação de conhecimento - reinventando a empresa com o poder da inovação contínua. Tradução de A. C. C. Serra. Rio de Janeiro: Campus, 2001.

LAKOMSKI, G. Moving knowledge: the problem of transfer and how to reframe it. In: PROCEEDINGS OF THE THIRD EUROPEAN CONFERENCE ON ORGANIZATIONAL KNOWLEDGE, LEARNING AND CAPABILITIES. Barcelona: 2003. p. 12-13.

MARR, B. Perspectives on Intellectual Capital. Burlington: Elsevier, 2005.

MARTINEZ-FERNANDEZ, M. C.; MILES, I. Inside the software firm: coproduction of knowledge and KISA in the innovation process. International Journal of Services Technology and Management, v. 7, n. 2, p. 115-125, 2006.

MATTHYSSENS, P.; VANDENBEMPT, K.; BERGHMAN, L. Value innovation in business markets: breaking the industry recipe. Industrial Marketing Management, v. 35, n. 6, p. 751-761, 2006.

MERRILEES, B.; RUNDLE-THIELE, S.; LYE, A. Marketing capabilities: antecedents and implications for B2B SME performance. Industrial Marketing Management, v. 40, n. 3, p. 368-375, 2011.

MILES, I. Knowledge intensive business services: Prospects and policies. Foresight, v. 7, n. 6, p. 39-63, 2005.

MILES, I. Knowledge intensive services and innovation. In: BRYSON, J.; DANIELS, P. W. (Ed.). The Handbook of Service Industries. Cheltenham: Edward Elgar, 2007. p. 277-294.

MILES, I. Knowledge services. In: HEARN, G.; ROONEY, D. (Ed.), Knowledge policy: challenges for the 21st century. Cheltenham: Edward Elgar, 2008. p. 11-27.

MILES, I.; KASTRINOS, N.; FLANAGAN, K.; BILDERBEEK, R.; DEN HERTOG, P. Knowledge-intensive business services: users, carriers and sources of innovation. European Innovation Monitoring System (EIMS) Reports. 1995. Available in: https://www.escholar.manchester.ac.uk/api/datastream?publicationPid=uk-acman-scw:75252\&datastreamld=FULL-TEXT.PDF. Access in: 20 nov. 2018.

MULLER, E.; ZENKER, A. Business services as actors of knowledge transformation: The role of KIBS in regional and national innovation systems. Research Policy, v. 30, n. 9, p. 1501-1516, 2001. 
Ronnie J-Figueiredo, Júlio Vieira Neto, João J.M. Ferreira, Osvaldo Luiz Gonçalves Quelhas, Gilson Brito Alves Lima

Knowledge creation and knowledge transfer: an perspective under the kibs vision for evaluating the innovative capacity

NÄHLINDER, J. Innovation in knowledge intensive business services: state of the art and conceptualizations. Working paper, Linköping University, 2002.

NARANJO-VALENCIA, J.; JIMENEZ-JIMENEZ, D.; SANZ-VALLE, R. Innovation or imitation? The role of organizational culture. Management Decision, v. 49, n. 1, p. 55-72, 2011.

NEU, W. A.; BROWN, S. W. Manufacturers forming successful complex business services: designing an organization to fit the market. International Journal of Service Industry Management, v. 19, n. 2, p. 232-251, 2008.

NONAKA, I.; TAKEUCHI, H. The knowledge-creating company. Oxford: Oxford University Press, 1995.

NONAKA, I.; TOYAMA, R. A. A firm as a dialectical being: towards a dynamic theory of a firm. Industrial and Corporate Change, v. 11, n. 5, p. 995-1009, 2002.

OLIVA, R.; KALLENBERG, R. Managing the transition from products to services. International Journal of Service Industry Management, v. 14, n. 2 , p. 160-172, 2003.

PATON, R. A.; MCLAUGHLIN, S. Service innovation: knowledge transfer and the supply chain. European Management Journal, v. 26, n. 2, p. 77-83, 2008.

POLANYI, M. The tacit dimension. Chicago: University of Chicago Press, 1996.

RICKARDS, T. Stimulating Innovation - A systems approach. London: Pinter, 1985.

ROGERS, E. Diffusion of innovations. New York: Free Press, 2003.

SABBAG, P. Y. Espirais do Conhecimento. São Paulo: Saraiva, 2007.

SANTIAGO JR, J. R. S. Gestão do conhecimento: a chave para o sucesso empresarial. São Paulo: Novatec, 2004.

SANTOS, R. N. M. Métodos e ferramentas para a gestão de inteligência e do conhecimento. Perspectivas em Ciência da Informação, v. 5, n. 2, p. 205215, 2007.

SBICCA, A.; PELAEZ, V. Sistemas de Inovação. In: PELAEZ, V.;

SZMRECSÁNYI, T. (Orgs.). Economia da Inovação Tecnológica. São Paulo: Hucitec, 2006. p. 415-448.

SHEEHAN, J. Understanding service sector innovation. Communications of the ACM, v. 49, n. 7, p. 42-47, 2006. 
Ronnie J-Figueiredo, Júlio Vieira Neto, João J.M. Ferreira, Osvaldo Luiz Gonçalves Quelhas, Gilson Brito Alves Lima

Knowledge creation and knowledge transfer: an perspective under the kibs vision for evaluating the innovative capacity

SIMMIE, J.; STRAMBACH, S. The contribution of KIBS to innovation in cities: And evolutionary and institutional perspective. Journal of Knowledge Management, v. 10, n. 5, p. 26-40, 2006.

SVEIBY, K. E. The new organizational wealth: managing and measuring knowledge-based assets. San Francisco: Berrett-Koehler, 1997.

SZULANSKI, G. The process of knowledge transfer: a diachronic analysis of stickiness. Organizational Behavior and Human Decision Processes, v. 82, n. 1, p. 9-27, 2000.

TETHER, B. S. Do services innovate (differently)? Insights from the European innobarometer survey. Industry \& Innovation, v. 12, n. 2, p. 153-184, 2005.

TETHER, B. S.; METCALFE, J. S. Services and systems of innovation. In: MALERBA, F. (Ed.). Sectoral systems of innovation. Cambridge: Cambridge University Press, 2004.

TIDD, J.; BESSANT, J.; PAVITT, K. Gestão da Inovação. 3. ed. Porto Alegre: Bookman, 2008.

TOMLINSON, C. Invitations to learn. Educational Leadership, v. 60, n. 1, p. 6$11,2002$.

TOMLINSON, M. Information and technology flows from the service sector: a UK-Japan comparison. In: BODEN, M.; MILES, I. (Orgs.). Services and the Knowledge-Based Economy. London: Continuum, 2000. p. 209-221.

VARGO, S. L.; LUSCH, R. F. Evolving to a New Dominant Logic for Marketing. Journal of Marketing, v. 68, n. 1, p. 1-17, 2004.

WAHREN, H. K. Erfolgsfaktor Innovation. Berlin: Springer-Verlag, 2004.

WELLMAN, J. L. Organizational Learning: How Companies and Institutions Manage and Apply Knowledge. New York: Palgrave Macmillan, 2009.

WENHONG, Y.; MIN, Y. The policy to promote the innovative development of knowledge intensive business services. International Journal of Business \& Management, v. 5, n. 11, p. 190-194, 2010.

WINDRUM, P.; TOMLINSON, M. Knowledge-intensive services and international competitiveness: a four country comparison. Technology Analysis \& Strategic Management, v. 11, n. 3, p. 391-408, 1999.

WOOD, P. Knowledge-intensive services and urban innovativeness. Urban Studies, v. 39, n. 5-6, p. 993-1002, 2002.

YANG, J.; YU, L.; LEE, C. C. The hidden value of knowledge in new products. Asia Pacific Journal of Management, v. 19, n. 4, p. 573-587, 2002. 
Ronnie J-Figueiredo, Júlio Vieira Neto, João J.M. Ferreira, Osvaldo Luiz Gonçalves Quelhas, Gilson Brito Alves Lima

Knowledge creation and knowledge transfer: an perspective under the kibs vision for evaluating the innovative capacity

ZALTMAN, G.; DUNCAN, R.; HOLBEK, J. Innovations and Organizations. New York: Wiley, 1973.

ZORTEA-JOHNSTON, E.; DARROCH, J.; MATEAR, S. Business orientations and innovation in small and medium sized enterprises. International

Entrepreneurship and Management Journal, v. 8, n. 2, p. 145-164, 2011.

\title{
CRIAÇÃO DE CONHECIMENTO E TRANSFERÊNCIA DE CONHECIMENTO: UMA PERSPECTIVA SOB A VISÃO DE KIBS PARA AVALIAR A CAPACIDADE INOVATIVA
}

\begin{abstract}
RESUMO
Introdução: A criação de conhecimento e a transferência de conhecimento constituem o campo de natureza interdisciplinar cuja configuração científica vem se consolidando no âmbito internacional a partir da sua relação com os Knowledge Intensive Business Servives (Negócios com Uso Intensivo de Conhecimento) - KIBS. Objetivo: Explicar como os elementos de um modelo conceitual baseado em KIBS podem ser aplicados de forma integrada para avaliar a capacidade inovativa de empresas no setor de serviços. Metodologia: A construção do modelo é baseada em uma análise bibliométrica do tema central KIBS, nas bases de dados Scopus e ISI Web of Knowledge (Web of Science). Resultados: Neste estudo, percebe-se que durante os dezessete anos de investigação, os autores não investigaram a relação entre os KIBS e a avaliação da capacidade inovativa das firmas no setor de serviços. Conclusão: A maior concentração dos artigos analisados investiga os atributos e os papéis dos KIBS para inovação. Uma oportunidade para avaliar a capacidade inovativa dos KIBS no setor de serviços.
\end{abstract}

Descritores: KIBS. Criação de conhecimento. Transferência de conhecimento. Inovação.

\section{CREACIÓN DE CONOCIMIENTO Y TRANSFERENCIA DE CONOCIMIENTO: UNA PERSPECTIVA BAJO LA PERSPECTIVA DE LOS KIBS PARA EVALUAR LA CAPACIDAD DE INNOVACIÓN}

\begin{abstract}
RESUMEN
Introducción: La creación de conocimiento y la transferencia de conocimiento constituyen el campo de naturaleza interdisciplinaria cuya configuración científica se viene consolidando en el ámbito internacional desde su relación con los servicios empresariales intensivos en conocimiento, del inglés Knowledge Intensive Business Services o KIBS. Objetivo: Explicar de qué forma los elementos de un modelo conceptual basado en los KIBS pueden aplicarse de manera integrada para evaluar la capacidad de innovación de empresas del sector de servicios. Metodología: La construcción del modelo se basa en un análisis bibliométrico de los KIBS, como tema
\end{abstract}

Inf. Inf., Londrina, v. 24, n. 1, p. $300-325$, jan./abr. 2019. 
Ronnie J-Figueiredo, Júlio Vieira Neto, João J.M. Ferreira, Osvaldo Luiz Gonçalves Quelhas, Gilson Brito Alves Lima

Knowledge creation and knowledge transfer: an perspective under the kibs vision for evaluating the innovative capacity

central, en las bases de datos de Scopus y de ISI Web of Knowledge (Web of Science). Resultados: En este estudio, utilizando el análisis bibliométrico, podemos ver la evolución del tema y los autores de artículos que no investigaron la relación entre los KIBS y la evaluación de la capacidad de innovación durante los diecisiete años. Conclusión: La concentración de artículos más alta investiga los atributos y los papeles de los KIBS en su relación con la innovación. Una oportunidad para evaluar la capacidad de innovación de los KIBS en el sector de servicios.

Descriptores: KIBS. Creación de conocimiento. Transferencia de conocimiento. Innovación. 